\title{
Romancing the Other: Arundhati Roy's The Ministry of Utmost Happiness
}

\section{Abstract}

Arundhati Roy's second and latest novel, The Ministry of Utmost Happiness — which took her ten years to write - is crammed full of misfits and outsiders, the flotsam and jetsam of India's complex, stratified society. The novel is inhabited by cohorts of others: hijras, political rebels, the poor, women who will not "know their place", and abandoned baby girls. The narrative of Roy's latest political romance shows these others carving out new spaces for themselves, defying convention, trying possible new lives, and testing out new roles. This article aims to look at the texture of romance in Roy's novels. Set within the narrative of Roy's romance with India's others, it focuses on the Tilo-Musa romance in The Ministry of Utmost Happiness and compares it with the Ammu-Velutha romance in the author's first novel, The God of Small Things, published in 1997. Romance in Roy's novels serves multiple purposes, as this article argues and unpacks. Mapping out the patterns of romance which Roy creates in both her novels, this analysis employs the trope of romance as a lens through which to offer a postcolonial reading of The Ministry of Utmost Happiness, which interpenetrates intimacy and desire and the political. Deconstructing the (remarkably similar) romances at the heart of both of Roy's novels reveals that her romances may not just be her rebuttal to India's wrongs, but may even constitute a form of political rescue. We conclude that, although Roy is purposeful in identifying and avoiding re-orientalist representations (Lau and Mendes, 2012; Mendes and Lau, 2015), her rejection of abjection and victimhood, and her overt celebration of larger-than-life others, may have subverted the inferiorizing of the other, without however decreasing the process of othering. 


\title{
Introduction: Roy's positioning and politicizing of fiction
}

\author{
Tell me the other story ... the one that's horrible and beautiful ... the love \\ story. Tell me the real story.
}

(Roy, 2017: 366) ${ }^{1}$

\begin{abstract}
Almost a decade prior to the publication of The Ministry of Utmost Happiness (2017), Roy voiced her anxiety over the domestication of nonfiction and the expectations and constraints that are placed on the nonfiction writer-cum-clerk: "I worry that I am allowing myself to be railroaded into offering prosaic, factual precision when maybe what we need is a feral howl, or the transformative power and real precision of poetry" (Roy, 2009: 3). In terms of deflecting the expected criticism of political bias, the flexible trope of romance in The Ministry of Utmost Happiness enables the novel to sidestep constraints of the factual and the prosaic. Romances are set against the backdrop of the political upheavals in post-Independence India. The interpenetration of intimacy, desire, and politics allows Roy to go beyond (or perhaps above) mundane daily political squabbles, recalibrating the prioritization of the emotional and the experienced.
\end{abstract}

Arundhati Roy's long-awaited second novel was published as expected amidst a furore of literary excitement. The Ministry of Utmost Happiness has been loved and reviled, lauded and condemned, reviewed and critiqued with vigour and animation. Reviewers and critics seem to broadly agree that The Ministry of Utmost Happiness is “a riotous carnival” (Aitkenhead, 2017: n.p.), "a hulking, sprawling story” (Sehgal, 2017: n.p.), "large and labyrinthine" with "a shaggy structure and polemical bent", and 
a "monumental and messy book" (Rooney, 2017: n.p.). The differences between reader responses lie in whether these traits are considered as strengths or flaws. As the storyteller-turned-guide, Roy comes under criticism when readers are discomfited by the sheer teeming sprawl of The Ministry of Utmost Happiness (in plot, cast, temporal, and geographical terms); Kathleen Rooney (2017) for example finding the narrative leading to "a bewildering lack of momentum and focus", Arifa Akbar (2017) complaining it is "diffuse, unfocused, 'everything and nothing' at once"; Alex Clark (2017) finding it "patchwork of narratives", and "a novel of maddeningly frayed edges, wonky pacing and occasional longueurs". Roy, however, explains that the alleged unwieldiness of her novel is a narrative device designed to challenge the supposedly correct structure and form that the novel is expected to conform to:

fundamentally, I think what I mean is that there is a danger of fiction becoming domesticated, you know, of too much of a product that has to be quickly described, catalogued, put on a particular shelf, and everybody has to know what is the theme. And, to me, I wanted to blow that open. (Roy, qtd. in Goodman and Shaikh, 2017: n.p.) Anita Felicelli (2017: n.p.), writing in the Los Angeles Review of Books, grasps that Roy's fiction uses both structure as well as content to critique: "If at times it's messy and unwieldy and hard to control, this chaos mirrors the identity of India itself".

In the past two decades since she shot to fame when The God of Small Things won the Booker Prize (1997), Roy has grown accustomed to the politics of her writing coming under attack, particularly from her compatriots. As such, she will have anticipated the conflation of her politics with the literary merit of her most recent work of fiction, ${ }^{2}$ and her defiance comes through in giving no quarter in terms of pandering to convention or tiptoeing around sensitive or complicated issues. Knowing well her assailants and deriders, Roy employs the narrative strategy of breaking away from "the 
ordinary sequential style of storytelling" as Laura Miller (2017: n.p.) observes, as a possible attempt "to suggest the cyclical nature of human cruelty and the exploitation and neglect of the poor by the rich". In genre terms, The Ministry of Utmost Happiness is a political romance in the sense advanced by Doris Sommer in her study of the inextricability of politics and fiction in the national, foundational romances of Latin America as a combination between "our contemporary use of the word as a love story" and a nineteenth-century understanding of the romance genre "as more boldly allegorical than the novel" (1991: 5). Ever preferring controversy to conformity, Roy sets out to create a particular reading framework in her most recent political romance which allows for an understanding The Ministry of Utmost Happiness as a national romance in Sommer's terms, i.e., one that is assumedly political and whose plot is "boldly allegorical". Her deployment of the trope of romance — and a failed or doomed romance at that - is a postcolonial strategy which enables her fiction to engage with India's insistent and oppressive othering of individual and minority and povertystricken groups. Othering has been well studied in terms of the common practices of Orientalism (Said, 1978). The purpose of insisting on an "us and them" and the maintenance of an ineluctable distance between us and them (with the "us" always keeping the upper hand and position of superiority), is precisely to legitimize the right to colonize, dominate, and oppress in an ingenious variety of ways. As Edward W. Said (1978) pointed out, the othered are essentialized, spoken of and for, but always silenced and excluded.

The theme of othering has been so extensively studied already in relation to Roy's writing as to be almost hackneyed, ${ }^{3}$ but the manner in which she once again deploys it in The Ministry of Utmost Happiness is nevertheless original, novel, and attention-grabbing. Roy firmly, even provocatively, thrusts her others into the faces of 
her readers in her refusal to let her fiction be domesticated. The thread of (doomed) romance runs like an irresistible undercurrent in her writing (though, given that this is the incorrigible Roy, the undercurrent may well be an undertow). Her romances, in both The God of Small Things and The Ministry of Utmost Happiness, which come laced with poignancy, parallel her depiction of an India — from Kerala to Delhi and Srinagar — on which she sticks umpteen warning labels.

Sheetal Majithia draws on Peter Brooks' (1995) influential theory of romance, or "melodramatic imagination", and undertakes a "rough translation" of his Europe-based theory (growing out of pre-modern Christian genealogies and assuming the secular modernity in Europe after the French Revolution as universal) into the context of postcolonial India. She notes how "many of the attributes of the melodramatic imagination as defined by Brooks — the pronounced emphasis on gesture, rhetoric, and expressiveness, for example — appear in the Indian context" (2015: 5). In the next sections, this article advances the argument that romance in Roy's novels, although just one of her many literary devices, functions as a transformative and heroic political rescue of the other in postcolonial India. Unpacking the trope of romance in these novels and reading them politically allows for a reconsideration of the theme of romantic love in postcolonial writing which has also been studied by Sommer (1991) and, more recently, Emily S. Davis (2013) and Majithia (2015).

\section{Unromantic romance}

Just delighting in all the crazies and the sweethearts, and the joy in the saddest places, and the unexpectedness of things.

(Roy, qtd. in Aitkenhead, 2017: n.p.) 
The Ministry of Utmost Happiness is, as reviewers have picked up, "the ultimate love letter to the richness and complexity of India" (Felicelli, 2017). It is Roy's expression of and testimony to her enduring attachment to her adopted city since the late 1970s, Delhi, as well as India, comprising layers of involvement and disillusionment, intertwined. Just as in The God of Small Things, where the writer "undermines a sense of celebratory nativism" (Tickell, 2003: 84), Roy’s romances are likewise ill-fated and pre-doomed in her second novel. Depicting hapless romances without futures in both her novels, the author resolutely breaks with the mould of "happily ever after", cautioning readers against believing in fairytale endings. Thus siting the beauty and joy of "true romance", it would appear that Roy would disabuse her readers that everything will work out fine. (At least, as far as India is concerned.)

This is the writer's testament to the brutal conditions under which love cannot flourish or is not allowed to. Love is permitted no space in which to exist within the stark political and social realities of India, and Roy underscores how injustices and oppressions stamp out the fragile potential of beauty and love. In fact, despite flashing a fin of optimism at the endings of her novels, it is a defiant optimism, an against-theodds optimism, which only serves to highlight the brokenness of Indian society.

As Madhumita Lahiri explains in her study of W. E. B. Dubois’s 1928 Dark Princess: A Novel, Dubois turned to the romance novel as a "move against demands of accuracy and comprehensiveness in representation" (Lahiri, 2010: 546). Lahiri explains that this enabled Dubois to create characters which cater to the imagined readership rather than to criteria of cultural accuracy or historical representation. Like Dubois's romance, The Ministry of Utmost Happiness also invests in a "transfigurative imagining", which is "referential in its very misrepresentation" (Lahiri, 2010: 545), 
designed to refuse the onus of being an informant or an emissary. This accordingly amounts to a refusal of postcolonial writers to be producing creations which are “constantly being (re)framed as anthropological evidence" (Lahiri, 2010: 546). Roy’s novels are, as Lahiri observed about Dubois's romance novel, laying claim to fantasy and desire in order to oppose an "oft simplified realism" which marks the subjects out as "as already and inescapably intellectually and emotionally deficient" (Lahiri, 2010: 546). The Ministry of Utmost Happiness features so many others that it is necessary for Roy to use form as well as content to counter the pre-existing biases and weight of expectations. It becomes vital to clear a space and find a way of presenting their stories afresh, of seeking not to deny their otherness, but to demonstrate that this is not grounds for othering.

It is certainly curious that in each of the novels, at the heart of the narrative, there is a tender love story — pre-doomed, of course. Romance may not at first seem the most obvious deconstructive tool of choice for postcolonial analysis. Neither of Roy's novels can be unproblematically situated within the romance genre; however, romantic love allows for the examination of otherness in these novels. It cannot be said that these romances are the catalysts for the plotlines, but in an understated manner they anchor the narratives. Although the romances are at the narrative heart of the novels, chronologically speaking (and in purely linear terms), Roy reserves the romances for the latter parts of the novels. Though not central to the storyline, love stories act as a trigger for many other subsequent shaping events in the novels. In The Ministry of Utmost Happiness, Tilo and Musa have their only time together as lovers on the houseboat in chapter 9, around pages 352-372 (of the 438-paged, 12-chaptered novel). In The God of Small Things, the romance is only written in chapter 21 , in the very closing pages of the novel, although it is predicted by many of the events which precede it. The placing of 
the direct interaction between the lovers and the consummation so close to the end of both novels may in part be Roy's flirtation with readers by keeping the best for last. More likely, it is Roy's way of creating further pathos by ensuring that the reader can never read of the romances with unalloyed joy, with their own pre-knowledge that, by that stage in the novels, all ecstatic love is doomed.

Despite her "delight" in lovers or sweethearts, in the timing and placement of the romances it is obvious that Roy does not necessarily want her pluralistic narrative, with its powerful social and political commentaries, to be primarily characterized by romance, notwithstanding that genre's centrality to the plotlines. The fact that Roy places not just love, but romantic love, and not just romantic love but romantic love between a heterosexual man and woman, and not just romantic love between heterosexuals but pre-doomed romantic heterosexual love at the heart of her works of fiction, is significant. ${ }^{4}$ This is relevant not least because she does it not just once but twice in two novels, and the two romances contain enough similarities to appear almost as templates of each other.

The Ministry of Utmost Happiness is dedicated to "The Unconsoled", with the epigraph reading, "I mean, it's all a matter of your heart" (vii). As this opening quote indicates, Roy is very concerned with emotions and affect - matters of the heart - in the midst of her depictions of bigotry, brutality, and blatant disregard of humanity. She insistently depicts "joy in the saddest places" (qtd. in Aitkenhead, 2017: n.p.). In both her novels, Roy frames romantic love between her protagonists as poignant by setting it amid that which is threatened and forbidden. She casts purity in and of love as snatched happiness, brief and transient moments of translucent beauty in an otherwise bleak landscape of injustice, waste, and sorrow. Roy's romances — between Velutha and Amma in The God of Small Things, and Tilottama and Musa in The Ministry of Utmost 
Happiness - are inevitably those where the lovers are in precarious social and political situations and will likely perish. Indeed, both heroes do perish tragically young, a loss to their lovers but a blow also to their causes.

Roy's lovers — in 1997 and again in 2017 — resolutely and repeatedly choose to defy their pre-ordained tragedy. They refuse to desist from the romance in the face of bitter opposition, despite knowing their romance has no possible future. Perhaps they exist in parallel to Roy herself, who refuses to stop loving Delhi and India, knowing full well the extent of the treacheries and perfidies her country's authorities and groups in power are (and have been) capable of, but refusing to give up hope. Echoing Majithia's argument, postcolonial melodrama is an apposite mode to express "the coeval but uneven experience of postcolonial histories and modernities" (2015: 7). Following this reasoning, the trope of romance in Roy's writings constitutes a form of rescue of societal and political woes, the lotus in the mud (as per the front cover of The God of Small Things for Flamingo-Harper Collins), the hope when there is no rational reason to hope. Roy's novels of doomed love act as a truly romantic response in its own right, and a characteristically original form of rebuttal designed to express political indignation and outrage.

The lovers are also risk-takers, a trait which Roy seems to admire. It would appear that Roy not only champions the underdog, but has a particular admiration or soft spot for those unafraid — or at least still willing — to defy the odds even when stacked high against them. These themes feature on the front covers of the novels. As mentioned, on the cover of The God of Small Things for Flamingo-Harper Collins, a tiny, pink lotus flower blooms in the mud, a flicker of bright sweet colour amidst the grime of dull greys and dark greens. Meanwhile the front cover of The Ministry of Utmost Happiness for Penguin Random House is a black and white (perhaps marble) 
tombstone — setting the stage for the novel's scenes set in graveyards — on which lies a single, tiny red (perhaps slightly desiccated) flower (possibly a small rose, as there are scattered rose petals of the same red on the back cover). Roy's depiction of hopeless (read futureless) but defiantly hopeful romances encapsulates her worldview regarding the national and global state of affairs. When asked who "The Unconsoled" of the opening epigraph are, Roy replies, “All of us, in secret, even if we don’t show it. Some of us do, and some of us don't. But I think the world is unconsoled right now", adding that the novel's title is not a satirical one, even though many may believe it to be (qtd. in Goodman and Shaikh, 2017: n.p.).

The use of the romantic as a postcolonial lens of analysis of the novel alternatively, as a tool of analysis for postcolonial novels — has not been particularly prevalent. In considering how medieval romance has conditioned the imperialist imagination, Christopher Warnes (2005) notes that romance was a discourse in early imperialism, and even then fantasy already functioned as political rescue from historical trauma (as he points to in the research of Geraldine Heng on the writing of medieval romance). Although medieval romance may seem to have a wholly dissimilar set of inflections from postcolonial romance, there are parallels to be drawn between Warnes' theory of romance and Roy's The Ministry of Utmost Happiness. With its touches of surrealism and the fantastical amidst the brutalities of war, Roy's. novel may indeed function as political rescue or safety vents in the grim depictions of socio-historical trauma. Warnes also notes parallels with the magical realism of a postcolonial writer like Salman Rushdie, which could serve to resolve "the antinomy that underpins imperial romance, thereby destabilizing the binaries - colonizer and colonized, knowledge and inscrutability, western and other — upon which the colonial fictions depend" (Warnes, 2005: 17). Although falling more within the trope of realism than 
magical realism, The Ministry of Utmost Happiness similarly seeks to destabilize and blur conventional definitions, to bring into question neat categorizations, and to drag the reader into what was formerly terra nullius.

In her challenge to imperial romance, curiously enough, Roy uses what Warnes calls "a language of awe" (2005: 15), as he cites Mario Vargas Llosa calling this type of writing "expanded, marvellous realism" (Llosa, qtd. in Warnes, 2005: 16). It is curious because this language of awe was used formerly in the writings of early Spanish explorers and conquistadors. Such writings were unsurprisingly filled with the exotic, as it was at the start of the Spanish conquest of the Americas when the preeminent literary genre in Europe was the chivalric romance, and "many of its values held sway over the minds of would-be adventurers and a public hungry for miracles" (Warnes, 2005: 15).

As demonstrated by some reviews of Roy's The Ministry of Utmost Happiness quoted in the previous section, Davis (2013) argues that novels which combine romance and politics are frequently met with unease by critics and reviewers or, at least, that their critical reception tends to vary widely. An example of this is the unfavourable reception met by the historical romance The Map of Love (1999) by the Egyptian-born novelist and journalist Ahdaf Soueif, nominated for the Booker Prize (Davis, 2013: 1). While it is possible to map common themes across Roy's The God of Small Things and Soueif's The Map of Love (and an overlapping history of nomination for the Booker), it is the embedding of romance in issues of class, race, and empire which appear to have predisposed the critics in The God of Small Things's favour. Unlike Soueif's historical romance which with its recourse to Palestinian politics had the effect of being unsettling to her critics, the imbrication of romance and politics won Roy the Booker "to much fanfare" (Davis, 2013: 99). 
Roy's strategic use of a language of awe and the generic markers of an expanded marvellous realism in The Ministry of Utmost Happiness undergirds her steadfast refusal to re-orientalize. Re-orientalism has been understood as the perpetration of Orientalism by Orientals, ${ }^{5}$ particularly through modes and discourses of representations. Re-orientalism points out that self-representation by Orientalism (particularly across considerable class differentials and other axes) is not exempt from being skewed, flawed, and partial, as a result of being Western-centric. Even while re-orientalizing, many cultural producers may in effect challenge the metanarratives of the West, but more often than not at the price of setting up new metanarratives which may also exclude, silence, and subalternize. In other words, they continue to other, which is a key trait of Orientalism. Although Roy attempts to steer clear of re-orientalizing in terms of viewing India and Indians through Western lenses, she does not desist from othering. In fact, she does so with a vengeance to subvert the effacing of the long-othered, throwing light on that which and drawing attention to those who have long been hidden or ignored.

Roy employs the narrative devices of heightened consciousness and drama to counter the normalization and familiarization towards atrocities and oppressions not only in India, but also on a larger scale, worldwide. Possibly, this is Roy's attempt to resensitize readers, renew their sense of shock and outrage, considering that "[m]elodrama works to saturate the banality of everyday life with moral significance" (Lahiri, 2010: 547).

Likewise, Roy's narrative strategies fit well with the aims of decolonial aesthetics in line with Walter Mignolo's theorization on "epistemic disobedience" and “decolonial freedom" (2009), which also seeks "options for liberating the senses" - in fact, decolonial love "seeks liberation from the legacy of colonial violence" 
(Transnational Decolonial Institute, 2011: n.p.). The decolonial perspective advanced by Mignolo aims to counteract the monoculture of knowledge which undergirds the hegemony of the "center" (i.e., Europe) in the process of knowledge production. According to this view, Europe's colonizing project established a hierarchical logic that located itself at the highest level of civilizational development and, consequently, the rest of the world in a state of barbarism (from which it needs salvaging). This imposition engendered, paradoxically, the necessary conditions for acts of "epistemic disobedience" and for the emergence of decolonial thinking. In this sense, decolonial aesthetics is part of a larger movement of contestation of the asymmetric power relations between the colonizer and the colonized that seeks to decentralize colonial geopolitics of knowledge. Discussing decolonial love, Junot Díaz observes that it is the kind of love that his characters "long for intuitively, [it] is the only kind of love that could liberate them from that horrible legacy of colonial violence" (Díaz, qtd. in Moya, 2012: n.p.). There is no doubt that Tilo and Musa's love relationship exists in valiant defiance of the legacy of colonial violence, even if the liberation the couple seek and find in their romance is but temporary and extremely short-lived. Brief as the romance is, however, its impact is lifelong — for Tilo at least — and sustains her continued struggle against powers which oppress.

Although there is a strong (predominantly female) readership of the romance genre in India, it is questionable to regard The Ministry of Utmost Happiness, despite the romantic love story it contains, as securely part of this genre. Analysing the reading of romance novels in India, Jyoti Puri (1997) cites Tania Modleski’s (1982) work highlighting that entering into the fantasy world of romances is a subversive psychological process masking the magnitude of women's discontent. Complementarily, Puri's own research finds that female readers of romance in India 
favour heroines who may be successful, independent, strong, and feminine, and may even challenge the gender hierarchy, but nevertheless still only "assert themselves within the confines of femininity" (Puri, 1997: 443). Roy's independent, strong, genderhierarchy-challenging women characters not only explode the confines of femininity and bear little resemblance to conventional romance novels, but create a whole new paradigm of romantic heroines, if indeed they are such. These are heroines who are eccentric, idiosyncratic, fairly intransigent, insistently autonomous, and recalcitrantly resistant to societal categorization. In this way they are markedly unfeminine, particularly within the parameters of Indian femininity.

Roy's heroines and romances are also out of sync with Janice Radway's (1984) research on how readers respond to popular romance novels. Radway finds that ultimately the structure of romance novels embodies a perpetration of patriarchal ideologies and social practices. Put differently, the configuration of a woman's journey to female personhood within romances is constructed and realized within the patriarchal culture. Roy's women characters seem to have realized full personhood before embarking on romances, which, while life-changing, are not so because the romantic relationships develop them into fully-fledged women. In her mischievous way, Roy focuses the key romance in The Ministry of Utmost Happiness on a woman who is "very, very strange — strong woman, though, you know? And a little bit—a little bit on the edge of crazy" (Roy, qtd. in Goodman and Shaikh, 2017: n.p.). Hers is a character probably unlikely to be regarded as a romantic heroine, whom Roy herself notes is "curiously alone", reserved and inexpressive: "a person whose quietness destabilizes people, $[\ldots]$ whose signs of being intimate with someone is $[\mathrm{sic}]$ to not greet them or, you know, to not change her expression when someone she loves comes" (Goodman and Shaikh, 2017: n.p.). Roy explains that, to her, Tilo is the fictional child of Ammu 
and Velutha of The God of Small Things had their story ended differently, and is therefore the younger sister of twins Esta and Rahel. This fairly romantic conceptualization of Tilo's provenance is not made visible in the novel and is known only to the author. That said, Roy can hardly be accused of being a romantic. Notwithstanding all the babies who appear in The Ministry of Utmost Happiness, Roy never allowed Ammu and Velutha any offspring, and has Tilo terminate her pregnancy of Musa's baby.

The romance genre, however, is a productive route into questioning the patriarchal order and even suggesting possible reconfigurations. Despite its heterosexual Tilo-Musa love romance, The Ministry of Utmost Happiness would not countenance the perpetration or reiteration of patriarchal ideologies of oppression; its predecessor $^{6}$ The God of Small Things introduces the readers to Love Laws, which Roy describes with her most biting disdain: "The laws that lay down who should be loved, and how. And how much" (1997: 33). The Ministry of Utmost Happiness is about Love Laws being broken, about the social and political dissonance of love as experienced and performed by others: “And so, all these stories somehow are about people who just don't fit into that grid," Roy explains, where a solidarity of the heart emerges, "based on unorthodox kinds of love — not even sexual love or anything, it's just based on humanness" (qtd. in Goodman and Shaikh, 2017: n.p.).

\section{Roy's recurrent romances: The God of Small Things and The Ministry of Utmost}

\section{Happiness}


My first novel was about a family, and this [The Ministry of Utmost Happiness] is most emphatically not about a family. If that had a broken heart, this has a shattered heart.

(Roy, qtd. in Penguin, 2017: n.p.)

When Arundhati Roy takes to writing about hearts, like families they have to be first broken (in The God of Small Things), and then shattered (in The Ministry of Utmost Happiness). Because Roy's romances set out to break the Love Laws for good, her lovers are acutely aware that they put their very lives on the line by daring to conduct their romances. The God of Small Things, as Bose points out, "depicts protagonists who are ready to break social laws and die for desire, for love" (1998: 59). Desire and devotion, sexual love or other kinds of love, appear important to Roy as fuel to empower rebellion and defiance.

Drawing on the Elizabethan connotation of consummation (in sexual intercourse) as dying, Roy's depictions of the consummations of the Ammu-Velutha and Tilo-Musa romances both have a strong frisson of danger and impending death. In The God of Small Things, the chapter in which the sexual consummation involving Ammu and Velutha happens is poignantly called "The Cost of Living", possibly because this relationship would directly lead to Velutha's death:

Had he [Velutha] known he was about to enter a tunnel whose only egress was his own annihilation, would he have turned away?

Perhaps.

Perhaps not.

Who can tell? (1997: 333) 
Roy continues the Elizabethan death-and-sex connotations in her description of the climax of the intercourse, "when he had touched the deepest depths of her, with a sobbing shuddering sigh, he drowned" (1997: 337).

In The Ministry of Utmost Happiness, Musa and Tilo both know — although possibly they hope against hope — that Musa's work as a militant in Kashmir will likely cost him his life. As such, Roy describes their consummation thus: "What happened that night on the HB Shabeen was less love-making than lament" (362). This pair of lovers make love with a gun under their bed, which Tilo carefully refrains from asking about. Danger and risk stalk Roy's lovers, which adds a further frisson to their consummation, it being quite closely shadowed by their imminent and predictable deaths. As Brinda Bose observes in The God of Small Things, but which also holds true for The Ministry of Utmost Happiness, they "[focus] on the lines that one cannot, or should not, cross - and yet those are the very lines that do get crossed, if only once in a while — and then that makes for the politics of those extra-ordinary stories" (1998: 61). Romances are set like gems within contexts of tragedy, hazard, the forbidden, and the transient: "For a fleeting moment they were able to repudiate the world they lived in and call forth another one, just as real” (362). Would these romances carry quite the same emotional impact if they were not such snatched moments? Would the romances resonate with such profundity if they were not doomed romances, preordained to have no possible future? In her interview with Amy Goodman and Nermeen Shaikh (2017: n.p.), Roy says happiness is fragile, impermanent, and may be found in the most unexpected places. It is Roy's mischievous delight to create the unexpected places in her writing which overturn convention and, with such charm, create pathos: "Sometimes you just snatch the moment, and that's the only real thing. These fragile victories that 
you snatch and fully live — that's wonderful in itself' (Roy, qtd. in Sinclair, 2017:

n.p.). Roy's leitmotif of romances-without-futures is of course a comment on how fraught Indian society is, to the point that moments of purity and beauty happen despite the world around them, rather than being facilitated by it. Roy writes of "ecstatic love even when faced with the prospect of annihilation" (10) — not "even when" but "precisely because". In the words of one reviewer (Sinclair, 2017: n.p.), "Characters find joy and love and friendship in the most inauspicious circumstances" indicating that "utmost happiness is sometimes possible".

Even Roy's non-sexual love relationships in her novels are acts of rebellion. When discussing how Anjum was spared in the massacre of Muslims at the Gujarat pogrom because she is a hijra ${ }^{7}$, Roy talks of loving the fact that Anjum is saved by the very identity which excluded her. Roy says Anjum wishes to understand the world for Zainab's sake, when she becomes her mother; in Roy's words, "She [Anjum] doesn't accept this grid. She breaks it, and comes out. [...] And that, for me, is so sweet" (qtd. in Aitkenhead, 2017: n.p.). In most of the key relationships in the novel, there is a breaking free from what Roy calls "the grid", otherwise known as the Love Laws:

There are all kinds of unexpected love in the book, not just between men and women. Even motherhood is unusual, there's a beautiful love between Saadam [sic] Hussain and Anjum, and all kinds of odd friendships. I think that between Musa, Tilo, Naga and Garson Hobart, what happens is that Tilo does not react in ways that women are expected to, and this puts everything out of kilter - everyone has to reimagine love, and no one is on a sure footing because of that. (Roy, qtd. in Penguin, 2017: n.p.)

'Out of kilter" is quite an accurate summation of much of Roy's fictional worlds; she delights in finding ironies and in reconciling the apparently irreconcilable. Having written of the high-risk, danger-filled (and -fuelled) romance of Tilo and Musa, she then 
goes on to tell us that "In matters of the heart, they had a virtual forest of safety nets" (368). These lovers find security in the most perilous situations, rescued as they are from the burdens of life in an unjust world by their trust in each other and their love relationship.

There are further parallels between the Ammu-Velutha and Tilo-Musa relationships worth noting in their reiteration in novels written 20 years apart, possibly signalling that these (to Roy's mind, at least) are integral elements of romances. One striking parallel is the similarity between how Ammu and Tilo both regard their lovers with some degree of wonder for being anchored in their worlds, all the more so because the women feel alienated from their own worlds:

[S]he saw that the world they stood in was his. That he belonged to it. That it belonged to him. The water. The mud. The trees. The fish. The stars. He moved so easily through it. (1997: 333-4)

She had always loved that about him, the way he belonged so completely to a people whom he loved and laughed at, complained about and swore at, but never separated himself from. (358)

Roy further elucidates in The Ministry of Utmost Happiness this marvelling on the part of one who stands outside her society, writing of Tilo: "Maybe she loved it because she herself didn't — couldn't — think of anybody as 'her people"” (358); "Since the day they [Tilo and Musa] decided to go their own ways, she had had no "people"” (359). The writer also presents the reconciliation of differences and indeed even the attraction of opposites as part of the magic of romance:

Her brownness against his blackness. Her softness against his hardness. Her nut-brown breasts [...] against his smooth ebony chest. (1997: 335)

They had always fitted together like pieces of an unsolved (and perhaps unsolvable) puzzle - the smoke of her into the solidness of him, the solitariness of her into the 
gathering of him, the strangeness of her into the straightforwardness of him, the insouciance of her into the restraint of him. The quietness of her into the quietness of him. (362)

The conjoining of such opposing others is represented by Roy as a thing of hope, perfect but delicate.

\section{The role of romance}

[Writing fiction] is a way of seeing. A way of thinking, it is a prayer, it is a song.

(Roy, qtd. in O'Yeah, 2017: n.p.)

In a work of literature which clearly champions the underdog, exploring what images such representations create is paramount. "When people say this business of 'she's the voice of the voiceless', it makes me crazy”, Roy snorts. "I say, 'There's no voiceless, there's only the deliberately silenced, you know, or the purposely unheard"' (qtd. in Aitkenhead, 2017: n.p.). Whether creating larger-than-life others is another form of fetishizing and exoticizing, and whether the representation of these exceptional others in The Ministry of Utmost Happiness actually does the subaltern classes a disservice because the vast majority will not be "special", "gifted", or “outstanding" as Roy's characters so clearly are - are some of the questions that need to be brought to the fore.

Some critics have found The Ministry of Utmost Happiness a little over the top with its misfits and others — "The endless parade of oddballs and eccentrics can get a little exhausting" (Aitkenhead 2017: n.p.). Roy retorts to such critics that India contains so many deemed as minorities, “and by minority, I'm still talking about millions of 
people - being forced to live in terror, being pushed to the bottom of the food chain, being unrepresented in the media, unrepresented in the judiciary, unrepresented in the bureaucracy, unrepresented in any way, you know" (qtd. in Goodman and Shaikh, 2017: n.p.). This proliferation of alterity not only justifies but practically necessitates the parading of a veritable army of others. However, by having a cast so vast, one of the consequent literary weaknesses, as picked up by Oeendrila Lahiri and others, is the flatness or typecasting of the characters, which in turn makes them re-orientalizing, even if inadvertently:

[The novel's] characters follow a predetermined trajectory and consequently do not develop. Tilo, Musa, Anjum and Saddam enter the plot as types: each is representative of an identity or allegiance, who rise and fall with the tide of events surrounding them. They are above reproach, modelling all that is morally good with those on the right side of history. [...]

Similarly, minor characters like Azad Bharti, Garson Hobart or even the Santhal domestic help (a sideways comment on indigenous-mainstream relationships), are created less to layer the plot and more to fulfil the task of political education that Roy has assigned them. (Lahiri, 2017: n.p.)

Or, as Paul Sehgal observes, "Roy will say of a character, "He was a very clean man. And a good one too", and he is swiftly, unequivocally pinned to the page" (2017: n.p.). The essentializing of characters re-orientalizes, but might this character simplification be a necessary literary device in the explanation of a complex India, Roy's form of shorthand to a global readership? Re-orientalism may be perpetrated for the same motives which characterized Orientalism, in this case to bring or domesticate the chaos of the others within the frame of understanding the self, with its particular world order. It is a paradox that as much as Roy seeks to explode authoritarian or establishment structures, she nevertheless has always been particularly noted for her gift in 
acclimatizing her reader to the structures of her unique fictional worlds. While Roy writes to break her society's Love Laws — which are not just about love but set out the networks and hierarchies of Indian society, and therefore what and how much would be permissible within those relationships — her fiction is not without its own laws, all the same.

So, despite Roy's reputation (which she seems to have embraced) for being an unorthodox and anti-establishment author, there are nevertheless instances in The Ministry of Utmost Happiness where she seems to be upholding convention rather than overturning it. Such instances include the clearly delineated morality of her characters, which, while its does not then render them at all two-dimensional, nevertheless leaves relatively little room for development. Yet another example of re-orientalism in The Ministry of Utmost Happiness may be observed in the way Roy supports the institution of the family — which may well be a fair reflection of Indian society — by having her misfits, like the hijras, attempt to create alternative families. In a similar manner, Roy's celebration of the resilience of the war-ravaged Kashmiris, of the calculated elimination of those that bear any form of alterity or difference, may run the risk of celebrating the power of endurance at the expense of the refusal to endure that which should not be endured.

It may well turn out that, in her romances, Roy is at her least non-re-orientalistic, and at her most edgy, where she trespasses most deftly and defiantly. In writing of romantic love, Roy is celebrating an innocence, a refusal to allow experience to entirely annihilate innocence, an innocence which should not exist that she creates in defiance of its hostile surroundings, which should not be able to exist but provides hope precisely because it manages to exist, and beautifully, even if only for mere moments. Roy's romances are rather like Roy's authorial/novelistic successes: unexpected, unorthodox, 
unlooked-for. The India of The God of Small Things and The Ministry of Utmost Happiness would hardly encourage even the most optimistic to hope for such glory either in romances or writing, and yet of course, out of precarities, marginal spaces, and subalternities, the most creative and scintillating emerge, given the surprising but well documented "ability of subaltern groups to develop oppositional agency even in extremely repressive contexts" (Nilsen and Roy, 2011: 11-12).

Perhaps, as Roy would have it, just as love has to be reimagined, so too must India be reimagined, in order that rescue (social, political, cultural) can be hoped for, a rescue requiring the type and texture of love recurrently featured in both her novels, a love which "celebrated (but never preached) the virtue of spirituality over sacrament, simplicity over opulence and stubborn, ecstatic love even when faced with the prospect of annihilation" (10). Roy's protagonists face death by defiantly flying the flag of love

— ecstatic love, at that. It would appear then that in order to go on loving Delhi and India, one has to remain a romantic, and be romantic enough to love against hope.

\section{References}

Akbar A (2017) The Ministry of Utmost Happiness by Arundhati Roy — review. Evening Standard, 22 June. Available at: http://www.standard.co.uk/lifestyle/books/theministry-of-utmost-happiness-by-arundhati-roy-review-a3571126.html (accessed 15 May 2018).

Aitkenhead D (2017) Arundhati Roy on why it took 20 years to write her second novel. The Guardian, 27 May. Available at: https://www.theguardian.com/books 
/2017/may/27/arundhati-roy-fiction-takes-time-second-novel-ministry-utmost-happiness (accessed 1 May 2018).

Batra J (2017) Politico-literary response to terrorism: A study of Arundhary [sic] Roy's The Ministry of Utmost Happiness. Humanities and Social Sciences Review 7(2): 429 438.

Bose B (1998) In desire and in death: Eroticism as politics in Arundhati Roy's The God of Small Things. ARIEL: A Review of International English Literature 29(2): 59-72.

Brooks P (1995) The Melodramatic Imagination: Balzac, Henry James, Melodrama and the Mode of Excess. New Haven, CT: Yale University Press.

Clark A (2017) The Ministry of Utmost Happiness by Arundhati Roy review — a patchwork of narratives. The Observer, 11 June. Available at: https://www.theguardian.com/books/2017/jun/11/ministry-utmost-happiness-arundhatiroy-review (accessed 15 May 2018)

Davis ES (2013) Rethinking the Romance Genre: Global Intimacies in Contemporary Literary and Visual Culture. New York: Palgrave.

Felicelli A (2017) Outside language and power: The mastery of Arundhati Roy's The Ministry of Utmost Happiness. Los Angeles Review of Books, 21 June. Available at: https://lareviewofbooks.org/article/outside-language-and-power-the-mastery-ofarundhati-roys-the-ministry-of-utmost-happiness (accessed 15 May 2018).

Goodman A and N. Shaikh (2017) Full extended interview: Arundhati Roy on Democracy Now! Democracy Now! 20 June. Available at: https://www.democracynow.org/2017/6/20/full_extended_interview_arundhati_roy_on (accessed 15 May 2018). 
Lahiri M (2010) World romance: genre, internationalism, and WEB Dubois. Callaloo 33(2): 537-552.

Lahiri O (2017) The Ministry of Utmost Happiness is timely, but not deserving of the Booker. The Wire, 1 September. Available at: https://thewire.in/books/ministry-utmosthappiness-arundhati-roy (accessed 30 April 2018).

Lau L and Mendes AC (eds.) (2012) Re-Orientalism and South Asian Identity Politics: The Oriental Other Within. London: Routledge.

Majithia S (2015) Rethinking postcolonial melodrama and affect. Modern Drama 58(1): $1-24$.

Miller L (2017) To overflow every division between human beings: Arundhati Roy's immensely rewarding The Ministry of Utmost Happiness. The Slate, 19 June. Available at: http://www.slate.com/articles/arts/books/2017/06/arundhati_roy_s_the_ministry _of_utmost_happiness_reviewed.html?via=gdpr-consent (accessed 10 June 2018). Mendes AC and Lau L (2015) India through re-Orientalist lenses: Vicarious indulgence and vicarious redemption. Interventions: International Journal of Postcolonial Studies 17(5): 706-727.

Mignolo, WD (2009) Epistemic disobedience, independent thought and decolonial freedom. Theory, Culture \& Society 26(7-8): 159-181.

Moya PML (2012) The search for decolonial love: An interview with Junot Díaz. Boston Review: A Political and Literary Forum, 26 June. Available at: http://bostonreview.net/books-ideas/paula-ml-moya-decolonial-love-interview-junotd\%C3\%ADaz (accessed 21 May 2018).

Nilsen AG and Roy S (eds.) (2015) New Subaltern Politics. Reconceptualizing Hegemony and Resistance in Contemporary India. New Delhi: Oxford University Press. 
O’Yeah Z (2017) Writing fiction is a prayer, a song: Arundhati Roy. The Hindu, 2 June. Available at: http://www.thehindu.com/books/arundhati-roy-on-the-ministry-of-utmosthappiness-writing-fiction-is-a-prayer-a-song/article18701769.ece (accessed 1 May 2018).

Penguin (2017) Arundhati Roy on The Ministry of Utmost Happiness. Penguin Random House. Available at: https://www.penguin.co.uk/articles/in-conversation/interviews /2017/may/arundhati-roy (accessed 15 May 2018).

Pratt ML (1999) Arts of the contact zone. In: Bartholomae D and Petroksky A (eds) Ways of Reading. New York: Bedford/St. Martin's, pp. 527-541.

Puri J (1997) Reading romance novels in postcolonial India. Gender and Society 11(4): 434-352.

Radway JA (1984) Reading the Romance. Women, Patriarchy, and Popular Culture. Chapel Hill, University of North Carolina Press.

Rooney K (2017) The Ministry of Utmost Happiness. Chicago Tribune, 19 June. Available at: http://www.chicagotribune.com/lifestyles/books/sc-ministry-of-utmosthappiness-arundhati-roy-books-0621-20170622-story.html (accessed 30 April 2018). Roy A (2009) Introduction: Democracy's failing light. In Listening to Grasshoppers: Field Notes on Democracy. Chicago, IL: Haymarket Books, pp. 1-29. Roy A (2017) The Ministry of Utmost Happiness. London: Penguin Random House. Roy A (1997) The God of Small Things. London: Flamingo-Harper Collins. Sehgal P (2017) Arundhati Roy's fascinating mess. The Atlantic, June/July. Available at: https://www.theatlantic.com/magazine/archive/2017/07/arundhati-roys-fascinating-

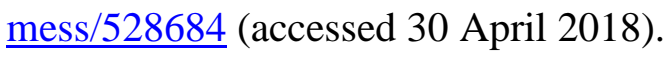


Sinclair C (2017) Arundhati Roy: Why happiness is a radical act. Vogue, 27 July.

Available at: http://www.vogue.co.uk/article/arundhati-roy-interview (accessed 1 May

2018).

Sommer D (1991) Foundational Fictions: The National Romances of Latin America.

Berkeley, CA: University of California Press.

Tickell A (2003) The God of Small Things: Arundhati Roy's postcolonial

cosmopolitanism. Journal of Commonwealth Literature 38(1): 73-89.

Tickell A (2007) Arundhati Roy's The God of Small Things. London: Routledge.

Transnational Decolonial Institute (2011) Exploring the Formation and Transformation

of the Darker Side of Modernity: Coloniality. Decolonial Aesthetics (I). 22 May.

Available at: https://transnationaldecolonialinstitute.wordpress.com/decolonial-

aesthetics (accessed 21 May 2018).

Warnes C (2005) Avatars of Amadis: Magical realism as postcolonial romance. Journal of Commonwealth Literature 40(3): 7-20.

Acknowledgements: With salutations and thanks to Dr R. Gunasekera for inspiring the theme, and to Dr K. Higgins and Dr A. Hastie for intellectual companionship at the inception of the case study.

\footnotetext{
${ }^{1}$ Subsequent references are to this (2017) edition of The Ministry of Utmost Happiness and will be cited parenthetically by page number in the text.

${ }^{2}$ Jagdish Batra, for example, accuses Roy of being influenced by terrorist camps, of having a dystopic worldview, and only showing "the ugly and the rotten side of the body politic" (431). Batra condemns The Ministry of Utmost Happiness because it "comes out of a political novel rather than a pure artistic attempt" (2017 435) - although it remains unclear what for him may constitute a "pure artistic attempt". ${ }^{3}$ See, in this respect, the section "The Subaltern" in Alex Tickell's critical survey of The God of Small Things (2007: 81-88), detailing the extent to which the concept of the subaltern has been mobilised in readings of Roy's first novel ever since its publication, and framed within a "preoccupation with oppressed social groups in India" in her literary and journalistic writing (2007: 82).

${ }^{4}$ The cadence of this sentence is obviously taking a leaf out of Roy's The God of Small Things, where she layers the undesirable attributes of Ammu's first marriage: "She subscribed wholeheartedly to the commonly held view that a married daughter had no position in her parents' home. As for a divorced daughter - according to Baby Kochamma, she had no position anywhere at all. And as for a divorced daughter from a love marriage, well, words could not describe Baby Kochamma's outrage. As for $a$
} 
divorced daughter from an intercommunity love marriage - Baby Kochamma chose to remain quiveringly silent on the subject" (Roy, 1997: 45-66; emphases added).

${ }^{5}$ For a more detailed discussion of re-orientalism theory and discourse, see Lisa Lau and Ana Cristina Mendes, eds. (2011) and Mendes and Lau (2015).

${ }^{6}$ Indeed, there is a very direct link between Roy's two novels: "Well, actually, to me, Tilo, Tilottama, is the fictional child of Ammu and Velutha in The God of Small Things, had their story ended differently. She's the younger sibling of Esthappen and Rahel" (Roy, interview with Goodman and Shaikh, 2017).

${ }^{7}$ Officially recognized as belonging to a third gender, a hijra is a South Asian eunuch, either a male who identifies as a female, or else a person of indeterminate sex. 